\title{
Comparative Study of Website Sitemap Feature as Design Issue in Various Websites
}

\author{
Jatinder Manhas $^{\mathrm{a}}$ \\ ${ }^{a}$ First Department of Computer Sciences \& IT, University of Jammu, Jammu, 181206,India
}

\begin{abstract}
Websites are very important for communicating organizational aims and goals in this current era of information technology. Different institutions / organizations put lots of efforts to portray complete information on beautifully designed websites. Lot of efforts are required by the designer / concerned organization to design websites according to the different website design standards to provide users with all the facilities of the concerned institutions / organizations online, which act as an online agent through which a user can get his work done without physically visiting the organizations. With this the responsibility of the designer and the concerned institutions / organizations increases manifold so that the websites behavior should remain interactive and quick enough for the user to avail provided facilities of the website comfortably. Sitemap provides with a logical overview of the path through which a user can navigate through a website. Without efficient and user-friendly navigation, the user is likely to get confused, lost, or frustrated and leave the site without getting their work done. Sitemap gives users with the graphical representation of Web pages on a Web Site and also present them with a complete alternative method of navigating the site. Author in this paper developed an online tool using .NET Framework using C\# to study webpage sitemap feature as Design issue in various categories of the websites like Government, Commercial, Educational, Social networking and Job portals. The automated tool developed by author function on the basis of the different standards prescribed in W3C WCAG 1.0 guidelines in priority 2 checkpoints 13.3 [5]. the developed tool act like a parser and renders the complete code of the website and produces results by determining the presence of the sitemap facility within the websites for easy content retrieval. The results produced shows that out of the five different categories of websites employed for analysis the commercial websites undertaken follow the maximum standards as far as sitemap parameter is concerned.
\end{abstract}

Index Terms: Website Design, World Wide Web Consortium, Sitemap, Tool.

(C) 2014 Published by MECS Publisher. Selection and/or peer review under responsibility of the Research Association of Modern Education and Computer Science.

* Corresponding author. Tel.: +91-9419173793

E-mail address: manhas.jatinder@gmail.com, jatindermanhas@jammuuniversity.in 


\section{Introduction}

Website is combinations of related web pages served through single domain. Numbers of different kinds of websites are there but the most widely used categories of the websites are Educational, Commercial, Government, social networking and job portals. These days it has become mandatory for and organization big or small to develop a website to render its services online through different networks. With increase in the number of websites and its popularity it becomes necessary for an organization to put lot of efforts to design websites carefully so that it can easily cater to the need of all the different categories of the users. A number of website design issues are there which needs to be kept into consideration while designing websites. One of the most important issues among all is the sitemap feature of the websites. A website with excellent content and facilities will be wasted if the user cannot find and access the information or facilities that they want. Providing user with the abilities to find and retrieve information from a website with comfort and ease helps in building audience for it. With the massive increase in the internet users due to low cost and easy availability of features and facilities, it has becomes mandatory for a website to implement strategies that will result in alternative navigation facilities to the website users to find required pages easily. It is very good practice to put a sitemap link in every page of the whole website. It helps the user to find the required page immediately and doesn't let them become lost. Numbers of different organizations are there which are responsible for developing and implementation of different website development standards.

To evaluate the website design according to the different standard so that it provide better interaction facilities to users different types of automated tool are available and to evaluate the websites design w.r.t. the standards developed by W3C, an automated tool is developed which will take URL of the website as an input and then parse the complete code of the website and compare it with the website code that it is written according to the standards of $\mathrm{W} 3 \mathrm{C}$ or not. The working of the parser / automated tool developed is explained in the below given diagram.

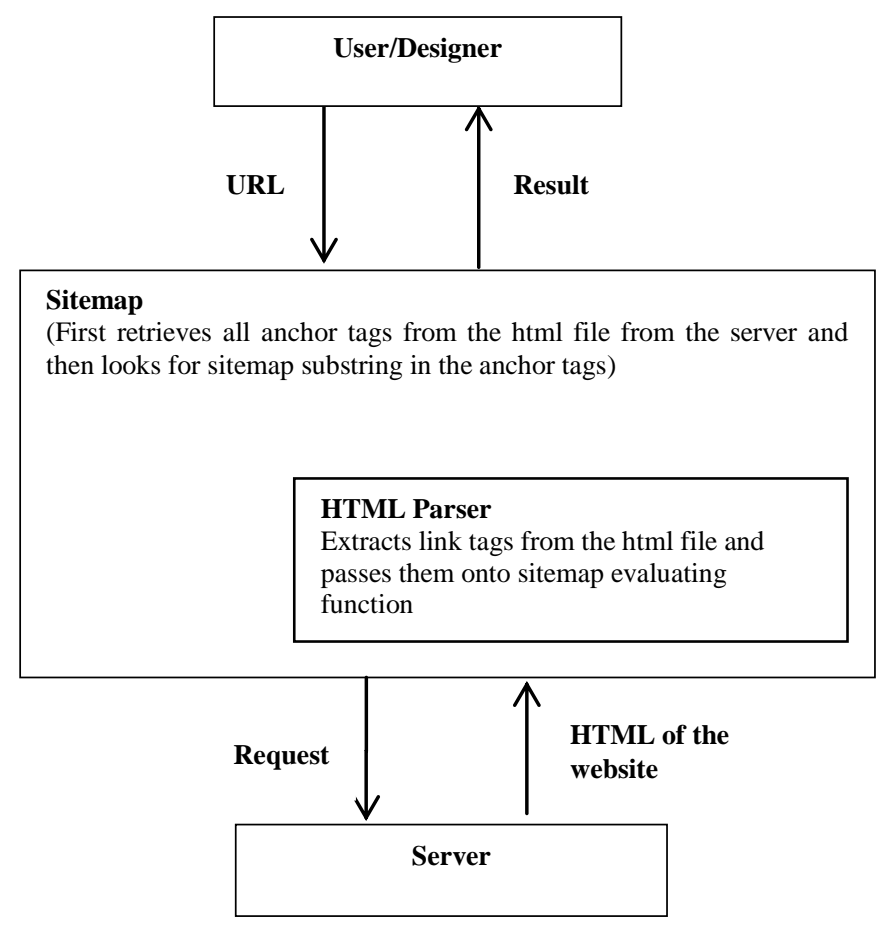


The parser will take URL of the website as input and then send it to the server and from the server HTML code of the website is supplied to the interface for making comparison with the existing standards. The algorithm of the automated tool developed is given below:

Algorithm 8: For determining sitemap in a website.

Input: URL of the website

Output: Presence or absence of sitemap

Method: (steps are numbered for better understand)

Begin

Step I: Generate a request for obtaining HTML file of the website by passing url to the server.

Step II: From HTML file determine all the anchor tags (link tag)

Step III: For Each anchor tag

Retrieve the character string (str) contained inside the tag.

Check for the substring "Sitemap" inside the string str.

Step IV: If for any (str contains ("sitemap"))

Sitemap present in website

Else

End

Sitemap not present in website

\section{Methodology}

\subsection{Problem Identification}

A website is comprised of many components and all components help in maximizing its performance and effectiveness. Effective websites generate an environment that is logical and does not confuse the user. A site with excellent content and facilities will be wasted if the user cannot find and access the information or facilities that they want. Providing user with the abilities to find and retrieve information from a website with comfort and ease helps in building audience for it. Without efficient and user-friendly navigation, the useris likely to get confused, lost, or frustrated and leave the site for good.

It is important to map a site out before inputting a single line of HTML. A large site with several underlying pages should have a map or guide that allows the user to jump to any page from any page [1][6][7]. Having a logical overview of the path you want the user to take will make it easier to develop a site that will direct them to where they want to go. When designing the navigation system it is important to think like someone seeing the site for the first time.

Site map check the navigation facility on the site as prescribed in W3C document WCAG 1.0 guidelines in priority 2 checkpoints 13.3[5]. It gives us the graphical representation of Web pages on Web Site. Site maps are easy to understand and present a completely alternative method of navigating the site to the user.It is very good practice to put a sitemap link in every page of the whole website. It helps the user to find the required page immediately and doesn't let them become lost [2].

\subsection{Online tool for testing websites}

The tool Website Design Evaluator developed for the purpose to determine the deviations in the design issues among different categories of websites from the standards provided by the concerned organizations considered various features of the design parameters. One of the important website design parameter considered in today's fast internet growing environment is sitemap [3]. Sitemap helps in providing a complete navigation facility to the website and hence provides away to jump between pages over a website. This tool evaluates presence of sitemap in a website by considering various properties of the sitemap component. The 
sitemap feature is determined by parsing all the link tags present in a website, retrieving the strings present inside these parsed tags and then searching for the 'sitemap' substring for a match within each string retrieved for the parsed link tags. The approach employed is fairly effective in finding out the presence of sitemap facility within a website.

\subsection{Sample Data}

The Sample data taken in gathering statistics for the sitemap parameter is given in the Table 1 below. A total of 100 websites belonging to different categories were considered. Since different categories of websites are designed in consideration with the constraints that apply to them as per the category they belong to. Therefore the diversity among the categories of websites considered helped in better understanding the variations in the features undertaken for the parameter and the statistics collected from the tool.

Table 1. Sample Data

\begin{tabular}{|c|c|c|c|c|c|}
\hline S.No. & Govt. Websites & Educational Websites & Commercial Websites & $\begin{array}{l}\text { Social Networking } \\
\text { Websites }\end{array}$ & Job Portal Websites \\
\hline 1. & www.mit.gov.in & www.upsc.gov.in & www.bsnl.co.in & www.facebook.com & www.monster.com \\
\hline 2. & $\begin{array}{l}\text { www.indianrail.go } \\
\text { v.in }\end{array}$ & www.shiksha.com & www.onlinesbi.com & www.gmail.com & www.careerbuilder.co.in \\
\hline 3. & www.moia.gov.in & www.apple.com & www.airtel.in & www.orkut.com & www.indeed.co.in \\
\hline 4. & $\begin{array}{l}\text { www.rajasthan.gov } \\
\text {.in }\end{array}$ & www.schoolcircle.com & www.india.philips.com & www.yahoo.com & www.simplyhired.co.in \\
\hline 5. & www.jkgad.nic.in & www.classteacher.com & www.libertyshoes.com & www.rediffmail.com & www.nakuri.com \\
\hline 6. & $\begin{array}{l}\text { www.maharashtra. } \\
\text { gov.in }\end{array}$ & $\begin{array}{l}\text { www.jammuuniversity. } \\
\text { in }\end{array}$ & www.bata.in & www.frenzo.com & www.glassdoor.com \\
\hline 7. & www.assam.gov.in & $\begin{array}{l}\text { www.kashmiruniversity } \\
\text { net }\end{array}$ & www.hp.com & www.bebo.com & www.usajobs.gov \\
\hline 8. & www.india.gov.in & www.coeju.com & www.tata.in & Www.goibibo.com & www.reed.co.uk \\
\hline 9. & $\begin{array}{l}\text { www.aponline.gov. } \\
\text { in }\end{array}$ & $\begin{array}{l}\text { www.kashmiruniversity } \\
\text {.ac.in }\end{array}$ & www.godrej.com & www.jakpinch.com & www.monesterindia.com \\
\hline 10. & $\begin{array}{l}\text { www.nagaland.nic. } \\
\text { in }\end{array}$ & www.jmi.ac.in & www.hul.co.in & www.myspace.com & $\begin{array}{l}\text { www.placementindia.co } \\
\text { m }\end{array}$ \\
\hline 11. & www.upsc.gov.in & $\begin{array}{l}\text { www.jamiahamdard.ed } \\
\mathrm{u}\end{array}$ & www.marutisuzuki.com & www.mycantos.com & www.timesjobs.com \\
\hline 12. & $\begin{array}{l}\text { www.petroleum.nic } \\
\text {.in }\end{array}$ & www.smvdu.net.in & www.britannia.co.in & www.friendster.com & www.beyond.com \\
\hline 13. & www.rbi.org.in & $\begin{array}{l}\text { www.islamicuniversity. } \\
\text { edu.in }\end{array}$ & www.pg.com & www.viber.com & $\begin{array}{l}\text { www.findtherightjob.co } \\
\text { m }\end{array}$ \\
\hline 14. & www.dotindia.com & www.du.ac.in & $\begin{array}{l}\text { www.colgatepalmolive. } \\
\text { com }\end{array}$ & www.netlog.com & www.bright.com \\
\hline 15. & www.coal.nic.in & www.jnuonline.in & $\begin{array}{l}\text { www.hindwarehomes.c } \\
\text { om }\end{array}$ & www.flickr.com & www.ziprecruiter.com \\
\hline 16. & www.tn.gov.in & www.amu.ac.in & www.pepejeans.com & www.watsapp.com & www.theladders.com \\
\hline 17. & $\begin{array}{l}\text { www.tourismofindi } \\
\text { a.com }\end{array}$ & $\begin{array}{l}\text { www.skuastkashmir.ac. } \\
\text { in }\end{array}$ & www.ashokleyland.com & $\begin{array}{l}\text { www.plus.google.co } \\
\text { m }\end{array}$ & www.monester.co.uk \\
\hline 18. & www.upgov.nic.in & www.skuast.org & www.dabur.com & www.tagged.com & www.career.com \\
\hline 19. & www.darpg.gov.in & www.pondiuni.edu.in & www.pepsico.com & www.ning.com & www.tweetmyjobs.com \\
\hline 20. & $\begin{array}{l}\text { www.guidelines.go } \\
\text { v.in }\end{array}$ & www.bujhansi.org & www.coca-cola.com & www.pinterest.com & www.smartbrief.com \\
\hline
\end{tabular}




\subsection{Results and Discussions}

The Statistics obtained after running all the above given websites on automated tool is collected in Table 2.

Table 2. Statistics

\begin{tabular}{|l|c|c|}
\hline Website Categories & $\begin{array}{l}\text { Sitemap } \\
\text { \%age of websites having } \\
\text { sitemap feature }\end{array}$ & $\begin{array}{l}\text { \%age of websites } \\
\text { without sitemap }\end{array}$ \\
\hline Educational Websites & 40 & 60 \\
\hline Job Portal Websites & 20 & 80 \\
\hline Social Networking Websites & 10 & 90 \\
\hline Commercial Websites & 80 & 20 \\
\hline Govt. Websites & 60 & 40 \\
\hline
\end{tabular}

\section{Graphical Analysis for sitemap:}

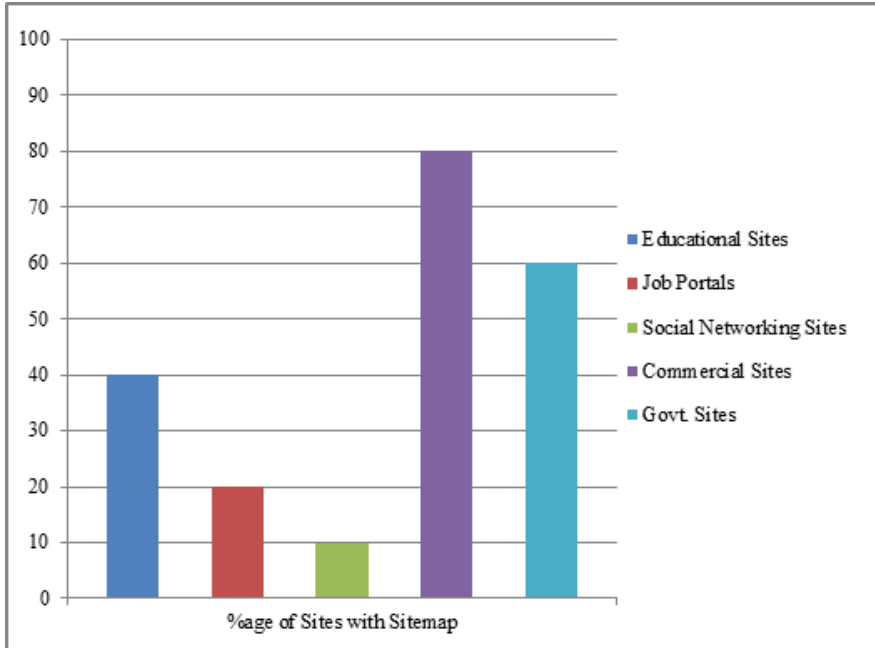

Based on the results taken from the above chart it is observed that the types of sites with maximum percentage of sitemaps availability are commercial sites and the sites with least percentage are social networking one's which means that out of the five different categories of websites employed for analysis the commercial sites follow the maximum of standards as far as sitemap parameter is concerned prescribed in W3C document WCAG 1.0 guidelines in priority 2 checkpoints 13.3 [5]. 


\section{Conclusion}

In order to better present on the website navigability factor, website designers should consider presenting a site map and keyword search engine for visitors [4]. After analyzing the results it is quite clear that majority of the website categories are not too much concerned about providing sitemap feature in their website instead of its importance in websites and a complete alternative approach for navigation.

Sitemap presents a graphical/geometrical 2D relationship among the webpages of a website. It's inclusion in the websites will help in easily navigating the webpage and hence will help in finding out the information available there with ease and comfort.

After evaluating websites on the developed tool it is observed that the websites arenot meeting various standards completely as proposed and recommended for the development of the website as they are incorporating every feature proposed by the concerned organization. It is clear that more efforts are required to meet with these criteria in the context of sitemap parameter for websites.

\section{Limitations}

There are various ways through which presence of sitemap within a website can be determined. Although the method used in Website Design Evaluator provides statistics regarding sitemap up to exact levels but the method involved may fail at instances. Almost all website designers provide sitemap via an anchor tag but certain designers though very few include sitemap within the design using sitemap tag inside the xml of the website. Website Design Evaluator determines the sitemap within the websites by parsing anchor tag but it fails to find out when designer has provided it within $\mathrm{xml}$ during the design. In websites where sitemap is included inside $\mathrm{xml}$ the tool is not able to determine its existence and hence provides incorrect statistics regarding them for this parameter.

\section{Future Scope}

In future the flaws that had left within the sitemap parameter will be considered for evaluation and will be included within the parameter to make it able to provide statistics that is always up to levels as expected. All the procedures through which sitemap can be included within the websites will be considered to determine its presence. The feature that is under consideration to be included is its existence via sitemap tag within the $\mathrm{xml}$ of the website to make this tool solution for maximum of the problems related to the site map parameter.

\section{Acknowledgements}

The author wish to thank Academicians and Designers working in different websites development houses for sharing their valuable thoughts related to website design. A special thanks to the world wide web consortium for providing such a beautiful design standards so that websites can be designed in a given set parameters to make website behaviors uniform for all types of different categories of the users.

\section{References}

[1] Dave Gehrke, Efraim Turban, Determinants of Successful Website Design: Relative Importance and Recommendations for Effectiveness, 32nd Hawaii International Conference on System Sciences - 1999.

[2] Purushottam Panta, Web Design, Development and Security, YOUNGSTOWN STATE UNIVERSITY, May 2009. 
[3] A. Andreatos, A Framework for Website Assessment, IEEE MELECON 2006, May 16-19, Benalmadena (Malaga), Spain.

[4] Shanshan Qi, Crystal Ip, Rosanna Leung, Rob Law,A New Framework on Website Evaluation, International Conference on E-Business and E-Government, 2010.

[5] http://www.w3.org/TR/WAI-WEBCONTENT.

[6] Sri Kurniawan, Panayiotis Zaphiris, Research-Derived Web Design Guidelines for Older People, School of Informatics, The University of Manchester, Center for Human-Computer Interaction Design.

[7] Michael O. Leavitt, Ben Shneiderman, Research-Based Web Design \& Usability Guidelines, Secretary of Health and Human Services, Professor of Computer Science, University of Maryland.

\section{Author(s) Profile}

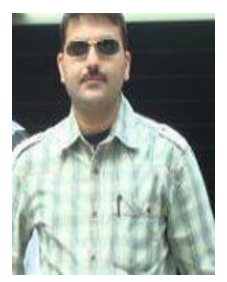

Jatinder Manhas. The author became a Member (M) of IACSIT on 16 September, 2014. The author belongs to the state of Jammu and Kashmir and born on $21^{\text {st }}$ March, 1980. The author's educational background includes masters in computer application from the university of Jammu, Jammu (J\&K), India in the year 2004. The author also qualified the state level eligibility test for lectureship in the year 2005 conducted by UGC. The Authors is likely to obtain $\mathrm{PhD}$ degree in the field of computer sciences and IT from university of Jammu (J\&K). The author's major field of study is website Design and Development issues.

He has represented 10 research papers in different national and international conferences within India and abroad. He has also published 8 research papers in different peer reviewed and indexed journals of international repute. The author is working as Sr. Assistant Professor in the Department of Computer Sciences \& IT, University of Jammu (J\&K), India since 2006. The author was also awarded with the UGC teacher fellowship under the faculty improvement programme to complete his $\mathrm{PhD}$ in the year 2012.

The author is also an acting and life member of Computer society of India and IACSIT (International Association of Computer Science \& Information Technology).

How to cite this paper: Jatinder Manhas,"Comparative Study of Website Sitemap Feature as Design Issue in Various Websites", IJEM, vol.4, no.3, pp.22-28, 2014.DOI: 10.5815/ijem.2014.03.03 